\title{
Hinterlands of Budget Air Travel Investigating the Journey of Aviation Fuel
}

Tunca Beril BASARAN, Technical University of Berlin, Germany Christina KRAMPOKOUKI, Technical University of Berlin, Germany Simon WARNE, Technical University of Berlin, Germany

Rosa Catalina Pintos HANHAUSEN, Technical University of Berlin, Germany

\begin{abstract}
This paper investigates the oil infrastructures, as intersections of trans-territorial networks systems of power and their exchange with local practices: the journey of Jet A1 aviation fuel that facilitates the budget air traveling in Berlin's airports, from crude oil extraction in Russia, distillation in Schwedt-Eastern Germany, to refueling off the aircraft by tanker truck sits source to its point of use. A case study focuses on the urbanism dynamics of Schwedt as an attempt to trace part of the planetary urbanism corresponding to Berlin's growing tourist industry's use of jet fuel. The first part of the research centers on oil landscapes' networks -the industrial footprint of oil: its transformation, storage, and transportation. Further provides a depiction of 'what constitutes aviation fuel and its production network' to view the actors involved in the process, the links between them, and the spatial implications. The second part addresses how aviation fuel has impacted Berlin and Brandenburg's hinterland: primarily, Schwedt, a shrinking city despite Berlin's recent boom, where the size of the traditional urban "city" form is diminutive in scale compared to the adjacent PCK oil refinery's "non-city" form of urbanization. The study's findings present new ways of interpreting and mapping the metabolic vehicles of planetary urbanization in both architectural and urban scales.
\end{abstract}

\author{
Keywords \\ Oil, Infrastructure, Hinterland, Planetary Urbanism
}

\section{Fuelling Budget Air Travel}

\subsection{Introduction}

Every month more than 3,1 million passengers fly in and out from Berlin-Schoenefeld airport; how many of them are aware of the process enabling this action? Berlin's magnitude for budget air traveling results from synergic relations between the city, its airports, and the oil industry. Petroleum-based Jet A1 fuel energizes the aircraft after traveling more than $5000 \mathrm{~km}$ through various pathways of infrastructures. This oil flow defines current and future spatial configurations on the earth's surface by generating fixed 
petroleum structures, such as landscapes that constitute drilling sites, refineries, pipelines, and even urbanism.

Brenner (2016, p. 125) explains these non-city spaces, such as hinterlands, which are usually hidden from the sight of everyday life. He criticizes the traditional urbanism approaches as being "locked into an externalist framework that attempts to distinguish them, analytically and spatially, from the city". Such a critique is particularly relevant in a context where Schmid and Brenner (2012, p. 5) define planetary urbanism as a "disintegration of hinterlands" as our urban networks and urban support systems sprawl beyond traditional city boundaries into former wildernesses and across borders. Furthermore, this multiscalar built environment necessitates utilizing process-oriented urbanization view in which these landscapes of production are considered to be as a part of the integral global urban condition (Arboleda, 2015, p. 2).

By engaging with an emergent strand of critical urban theory, this paper investigates the oil infrastructures, as intersections of trans-territorial networks systems of power and their exchange with local practices: the journey of Jet A1 aviation fuel from crude oil extraction in Russia, distillation in Schwedt, to refueling off the aircraft by tanker truck sits source to its point of use. The core of the paper focuses on the urbanism dynamics of Schwedt as an attempt to trace part of the planetary urbanism corresponding to Berlin's tourist industry's use of jet fuel. Centering on petroleum in the built environment The purpose is to understand how petroleum stitched into spatial practice to understand how these forms shape our future. For this reason, the paper underpins the findings of a seminar series taught by the Habitat Unit at the Technical University of Berlin conducted in April 2019.

The following sections provide a detailed view of the networks of oil landscapes formed by physical infrastructures and social, economic, and political processes. The first part of the research centers on oil landscapes' networks -the industrial footprint of oil: its transformation, storage, and transportation. Further provides a depiction of 'what constitutes aviation fuel and its production network' to view the actors involved in the process, the links between them, and the spatial implications. The second part addresses how aviation fuel has impacted Berlin and Brandenburg's hinterland: primarily, Schwedt, a shrinking city despite Berlin's recent boom, where the size of the traditional urban "city" form is diminutive in scale compared to the adjacent PCK oil refinery's "non-city" form of urbanization. The study's findings present new ways of interpreting and mapping the metabolic vehicles of planetary urbanization in both architectural and urban scales.

\subsection{Background}

"The fuels used for contemporary mobility systems rely on the mobility systems of fuel." (Marriott and Mino- Paluello, 2014: 3)

The oil industry functions by moving and shifting elements throughout the territory. From the crude oil extraction point to the refueling tank, the process requires the flow of materials, machinery, energy, and labor, among many others. On the other hand, this broad network across diverse matters, the Jet A1 fuel for this case, is in constant motion, change, or reloading. Thus this network generates a landscape by implementing a physical infrastructure that enables quantitative flows of materials and labor, 
outsourcing, and services. The nature of the product and both the production process's economic and physical organization has its implications of spatial configurations. Therefore, this section demonstrates how production Jet $\mathrm{A} 1$ is a matter of technical interest and includes social, economic, and political dimensions by reframing it in three investigation levels.

\subsection{The Product}

Jet $\mathrm{A} 1$ is a petroleum-based fuel that is designed to power modern commercial aircrafts with gas-turbine engines. It is produced from crude oil by processes of multiple distillation in high temperatures in a refinery. Its energy dense, storable and mobile nature makes it convenient for contemporary mobility systems including civil aviation activities. The liquid and lightweight character of oil enables a 'smooth' cargo system, which is based on zero storage and constant motion (Levinson, 2008, p. 24). It is economically attractive to the long distance transport between zones of production to consumption. Therefore liquidity of Jet A1 is extremely crucial, otherwise it would be hard to organise and transfer, so ensuring that each day more than 8 hundred barrels of Jet $A 1$ is delivered from PCK oil refinery in Schwedt to Schönefeld airport 'ready to fuel' the trips of off budget air travellers. It is is transferred into tanker trains, tanker trucks, tanker ships, or pipelines and once at the airport, the fuel is stored in tanks with water drains at their lowest point. When it comes to storage, the 'water phase' is the primary concern; prevention of slug water into the aircraft and protecting the product from contamination. However, if the proper conditions are satisfied, fuel can be stored indefinitely (Visser, 2011, p. 2). On the last stretch of Jet A1's journey to its final destination, smaller tanker trucks pick up the fuel directly in the tank farm and then head back to the boarding gates, where planes await refueling.

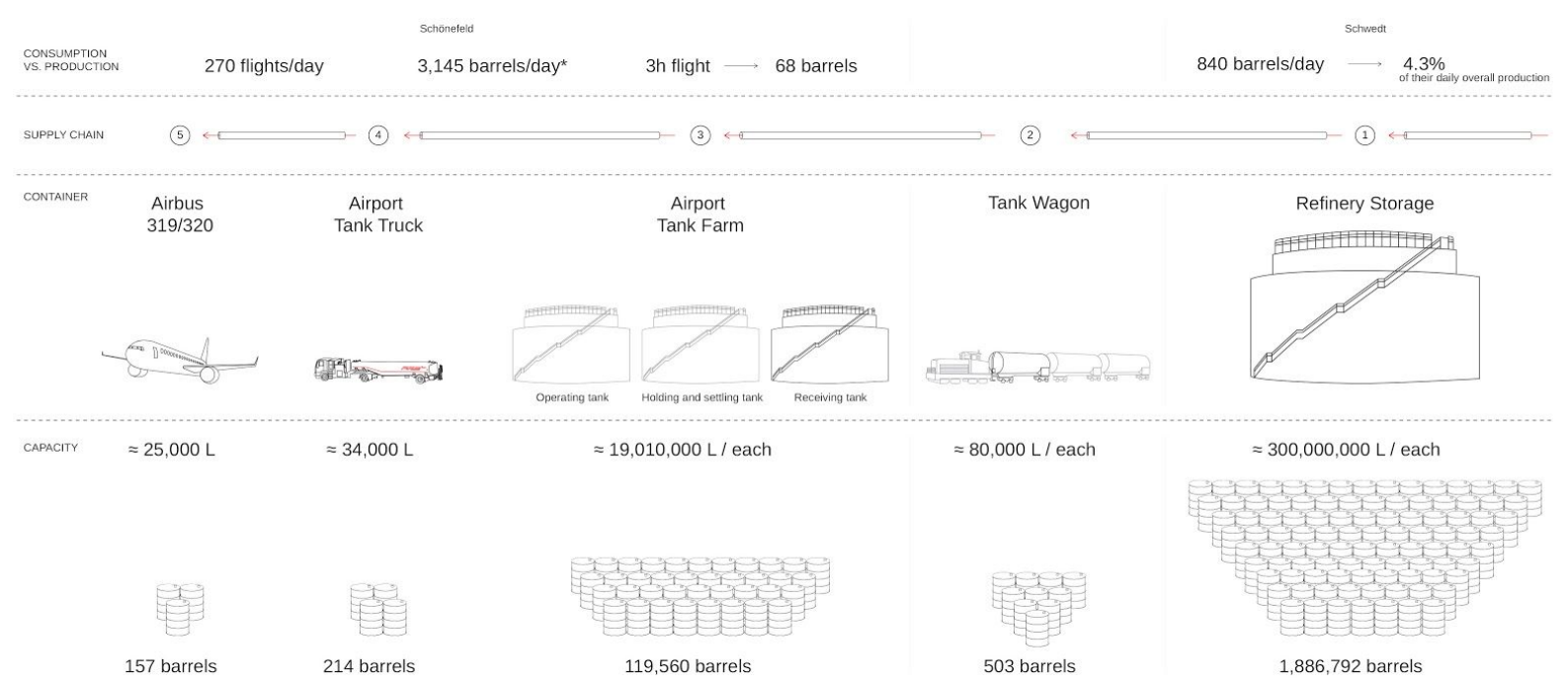

Figure 1. Comparison of consumption vs production of Jet A1 fuel. Source: Diagram by authors.

\subsection{Infrastructure Network}

In Berlin's case, its two airports are the places where the output of the global oil flow is transferred from the industrial scene to everyday life. Tegel, located in the west, receives around 30 tanker trucks a day by land connections. On the other side of the city, Schönefeld is located on the east and supplied via tanker 
trains directly from the railroad. PCK serves these two airports which is a refinery from the GDR-era located in Schwedt/Oder next to Poland, and strategically located on the Druzhba (Friendship) pipeline.

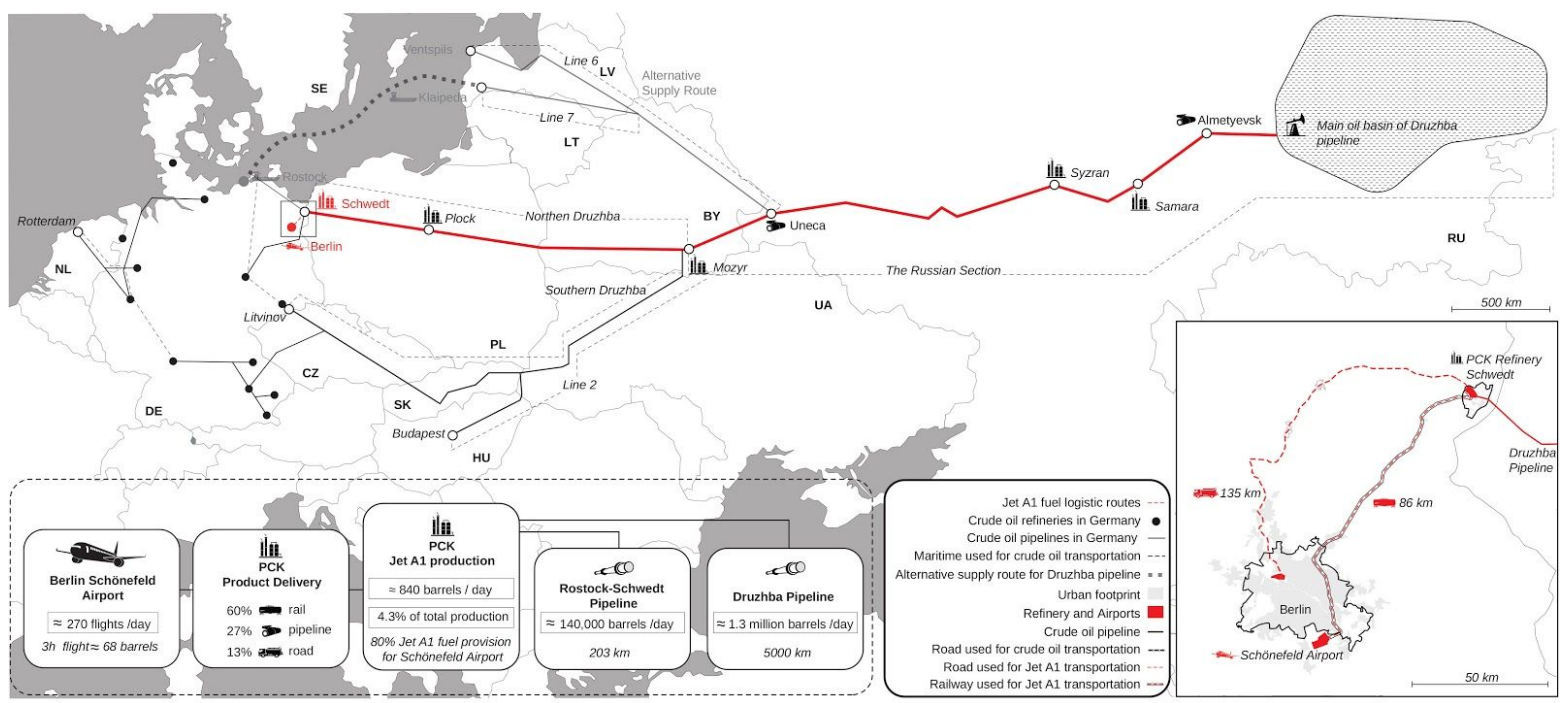

Figure 2. The route and branches of Druzhba Pipeline. Source: Diagram by authors.

Availability of raw crude oil and intentions to strengthen the economy with Western end of the socialist states, Soviet Union initiated Druzhba pipeline. It is constructed as a trunk crude oil pipeline, with three branches constructed in time, that carries oil from Eastern Russia over 4,000 kilometers passing through seven countries. In this regard, Savitzky and Urry highlight the key of logistics infrastructure by stating that "the uneven geographical distribution of fossil fuels necessitates long distance distribution of paths of pipelines, from extraction points to concentrations of people,machinery or industry, without an infrastructure to distribute energy, reserves are useless" (2019, p. 182).

In parallel, Council for Mutual Economic Assistance (Comecon) prioritised the project and completed the construction of Northern branch of Druzhba within in three years("PCK-Raffinerie Erdölverarbeitungswerk in Schwedt/Oder in Brandenburg" 2019). According to Druzhba Pipeline reports, it was a product of an international collaboration, where pipes manufactured in the Soviet Union and Poland, fittings provided from Czechoslovakia, the GDR controlled pumps, and Hungary provided the automation and communication equipment ("Druzhba Pipeline" 2019). In respect to that, the magnitude of associated corporations attracts further large-scale economic capital investments and reframes the local geography by introducing new structures (Sordi, Valenzuela and Vera, 2017, p. 217). For instance, the construction of PCK Schwedt is followed by more investments around the region, a second new plant in Leuna, and further infrastructural developments, including a new pipeline. These developments created an economic competition between regional administrations and various cities about the location of new factories (Lesh, 2000, p. 401). Today the refinery receives crude oil directly from the Druzhba pipeline; however, in exceptional cases (Harper 2019), the oil can also be delivered via the Rostock-Schwedt Crude Oil Pipeline ("Schwedt Refinery" 2015). 


\subsection{Production Network}

Jet A1 fuel's production network requires a coordinated set of activities and highly operational economic collaboration on a broad spatial scale. It is a product of institutional actors' decision-making on an international and local scale with varied shares in operation. For instance, large-scale infrastructure and industrial complexes such as pipelines, refineries, and ports are invariably owned and operated by holding firms representing at least one of the world's largest oil companies.

Nevertheless, the involvement of transnational cross-border companies is demonstrated most clearly in the PCK refinery in Schwedt. In the 1950s, the GDR was the largest importer of Soviet oil, all going to the petrochemical combine at Schwedt. Petrochemische Kombinat (PCK) was established as a state company in 1958 by the socialist German Democratic Republic (GDR). The refinery was issued as a part of five-year economic development plans, and Schwedt started processing Soviet crude oil in 1970. The explosion in world oil prices in 1973 set in motion forces that shape the economic relationship for the next decade. The production of refineries was affected by the oil crisis. In the early 1980s, Moscow reduced annual oil shipments, including 2 million metric tons of crude oil, almost half of oil deliveries to GDR. However, it was crucial for East Germany to maintain economic partnerships with the Soviet Union. Even after cuts, GDR received about $\% 73$ of its oils. Minerals Yearbook reports that the refinery had a refining capacity between 160-180 barrels per year (1980, pg. 73). Following German reunification in 1991, it was privatized and then sold to a coalition of the German, Italian state oil companies and a joint-venture of TOTAL. In 19946.8 million tons of crude oil processed almost less than half of the amount compared to a decade ago.

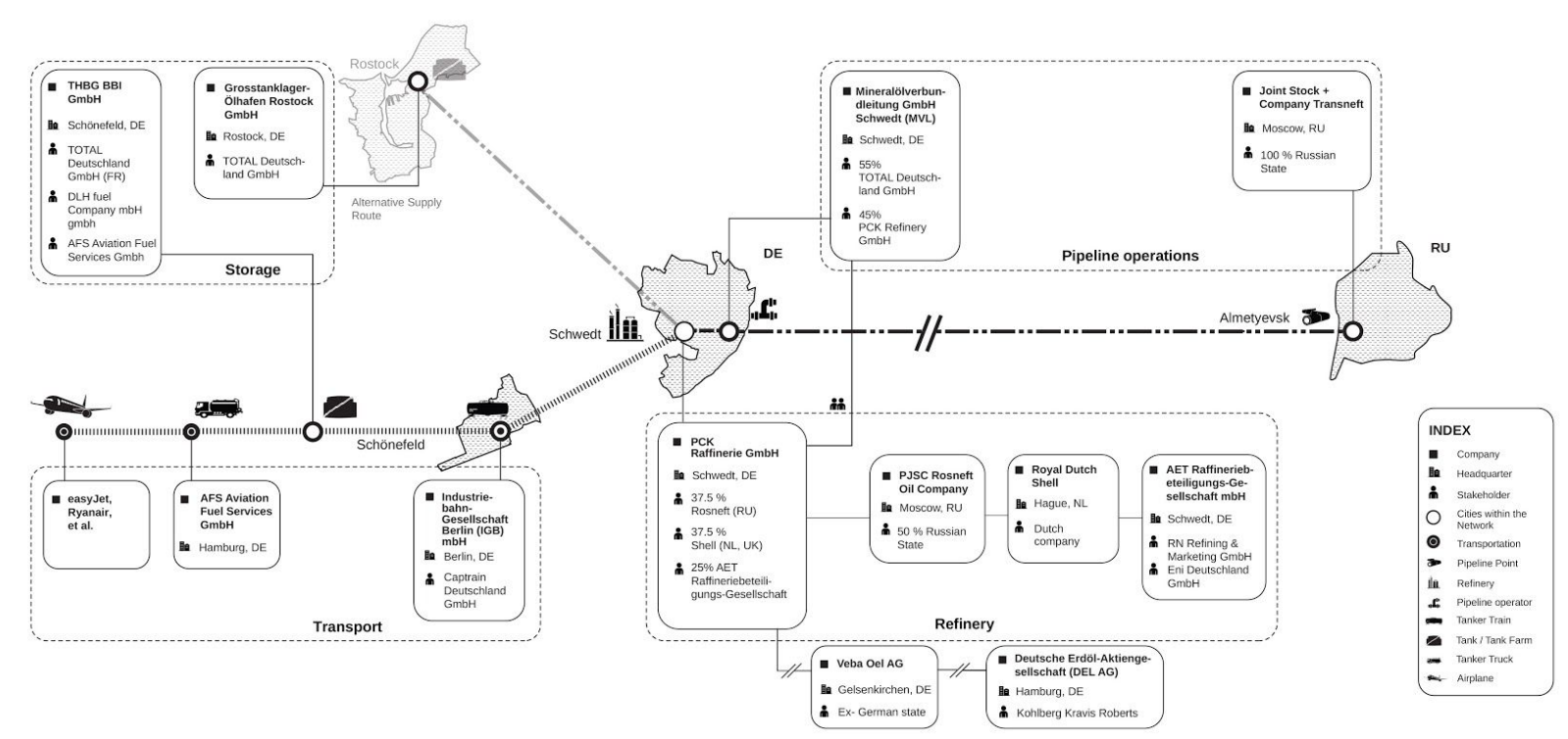

Figure 3. The Stakeholders of Jet A1 production. Source: Diagram by authors.

In more recent times, the Dutch oil company Shell and the Russian-state company Rosneft were major joint shareholders of PCK with 37.5\% each, until 2014, when a Russian company Rosneft bought TOTAL's $16.6 \%$ ownership, thus positioning themselves as the most dominant PCK shareholder ("Rosneft", 2015). This Russian company holds shares not only in this refinery but also in four others in Germany. Rosneft is an example of a leading global firm playing a pivotal role in shaping and coordinating global production, 
attempting to strengthen its position in one of Europe's most efficient refining centers and to use the opportunity to serve final customers in its most important market.

In the case of logistical issues, Jet A1 aviation fuel articulates a transnational network of production, organized and controlled mainly by leading global lead firms, but also involving smaller ones. The network reveals critical linkages between multi-scalar actors and regions, shifting and changing with different flows to create new geographic and economic patterns. To illustrate this point, the operation of the Druzhba crude oil pipeline is handled by both the Russian-state company Transneft, and TOTAL, a French multinational oil and gas company considered one of the world's seven 'supermajor' oil corporations (Bergin 2008).In contrast, smaller scale sections of the production chain, such as distribution by road or rail, are usually taken care of by smaller domestic or local firms. The final product of jet fuel is transported by rail tanker to Schönefeld airport by the domestic company IGB, based in Berlin, from where it is transferred by refuelling truck to the aircraft by the German company AFS, based in Hamburg. However, in-between these stages, the fuel is stored in a large airport tank farm, which is owned and operated by a local holding company representing key multinational oil industry players, including TOTAL, a key player who own and operate numerous other tank farms, including at the port of Rostock (Sternberg 2016).

\section{The Oil Urbanized}

\subsection{New Industrial Turn}

This part of the research focuses on Jet A1 fuel's urban footprint, extending across the territory as a productive transformational process. This urbanization pattern is closely linked with industrial operations facilitated by highly specialized infrastructure, labor, and specialized management organizations. Furthermore, the geographical flow of oil requires site-specific transformations between territorial scales and traditional urban limits, over administrative and political boundaries. (camp city) To illustrate the urbanization dynamics of oil, we present empirical research of a city that facilitates Berlin's airports.

Schwedt is a small-sized city in northeastern Brandenburg, with approximately 29.680 inhabitants according to the last census ("Schwedt." 2019). Formerly known as a rural town with tobacco production, the settlement was always a part of regional agricultural trade and production networks through the centuries due to its strategic location between other trading cities. However, by the end of the Second World War, Schwedt suffered from was nearly destroyed; $85 \%$ of the city was destroyed and lost its networks with other cities with blown-up bridges and burned locks. The post-war period was a golden age for Schwedt; under the rule of German Democratic Republic, the town was reconstructed and rapidly grew through extensive industrial development. First, a paper factory opened in 1959, which followed the crude oil processing plant, "Das Petrochemische Kombinat Schwedt" in 1963.

The arrival of the large-scale transnational industry to Schwedt distorted the patterns of metabolic flows that had always gravitated around agriculture and thus changed the city's faith. With continuous investments, Schwedt was to become a symbol in the early 1960's East Germany into a center of the oil industry. Furthermore, expanding patterns of the oil not only circumscribed to capital and infrastructure but also became an agent for stating political power and realizing state idealism. Accordingly, the tiny war-devastated city of Schwedt was chosen by GDR leaders to become one of four new Socialist Cities as flagships of the Five-Year-Plans. Characteristically, all these cities were built from scratch, linked to massive industrial development, and perceived as experimental areas for the new society. They were conceived as complete, coherent urban places and imagined as "splendid living environments, 
economically and culturally, that would promote the collective life of mankind." (Wakeman, 2014, p. 120) In contrast, for the case of Schwedt, Springer demonstrates that the "establishment of Schwedt there is no notions of a socialist city, rather the decision centered upon where one might best place the oil refinery around which the town was to be built." (Springer, 2007, p. 67).

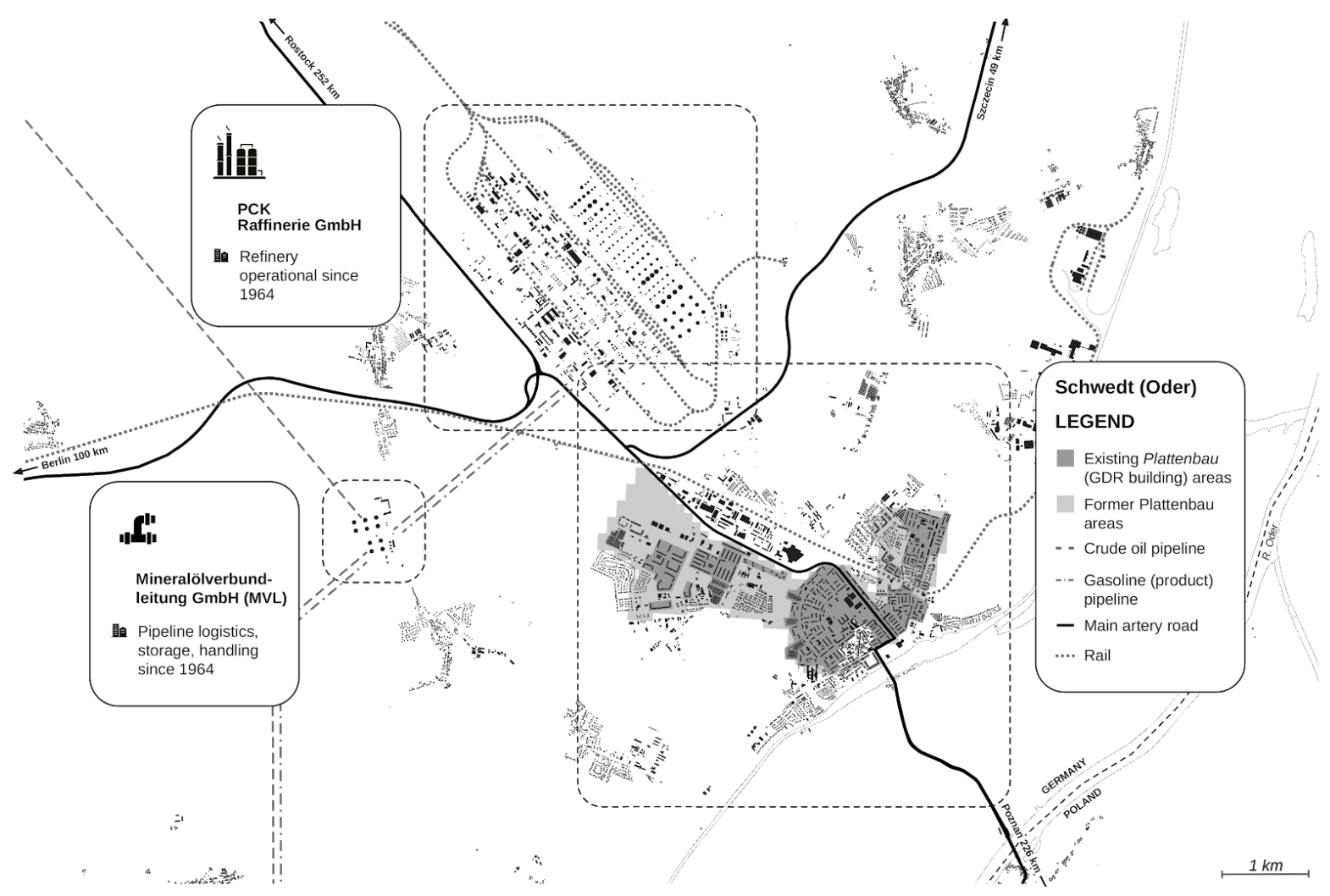

Figure 4.Oil infrastructure in Schwedt Source: Diagram by authors.

In that regard, Brenner comments that "the spaces of non-city have been continuously operationalized in support of the city-building process through the global history of uneven capitalist development." (2016, p. 125). As the word non-city refers to the rural, countryside and, urbanization is under relentless transformation, which is explained as a result of specific agglomeration patterns and where large-scale industrial operations occur. Furthermore, these non-city spaces are often located at a considerable distance from the main centers of capital, remaining out of sight for city dwellers. In other words, they are hinterlands where the metabolic exchange takes place to enable flows of certain materials, machinery, or products.Furthermore, Schmid and Brenner elaborate on the topic and discuss planetary urbanism to describe "the disintegration of hinterlands" as urban networks and their supplying infrastructures sprawl beyond traditional city boundaries into the former wilderness and across borders (2012). The term 'hinterland' defines various non-city spaces that are both outcome and suppliers of urbanization, whether as diverse types of settlements (towns, villages, hamlets), land-use configurations (industrial, agrarian, extractive, energetic, logistical), or ecologies (terrestrial, oceanic, subterranean, atmospheric)(Brenner and Katsikis, 2020, p. 24). Indeed, hinterlands like Schwedt, which are completely designed to provide materials such as Jet A1 fuel destined for consumption in remote areas to production, are the spatial imprints of these disintegrated and expanded metabolic exchanges. 


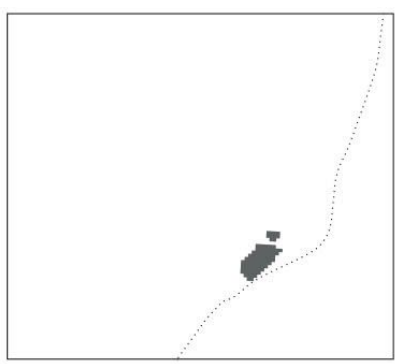

1960: Schwedt is a small village (grey), damaged from WWII

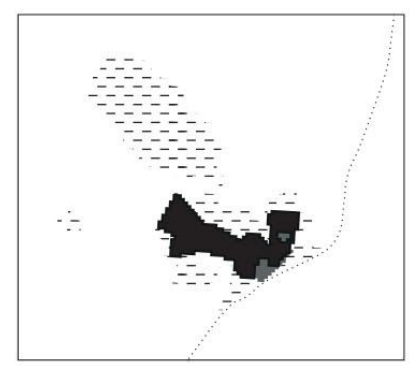

1990: Schwedt's peak with 54,000 people and $90 \%$ in Plattenbau socialist housing (black).

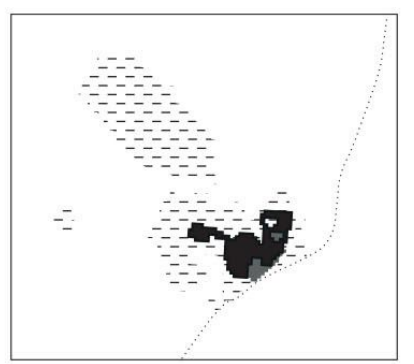

2020: A city in managed decline with extensive demolitions of Plattenbau socialist housing

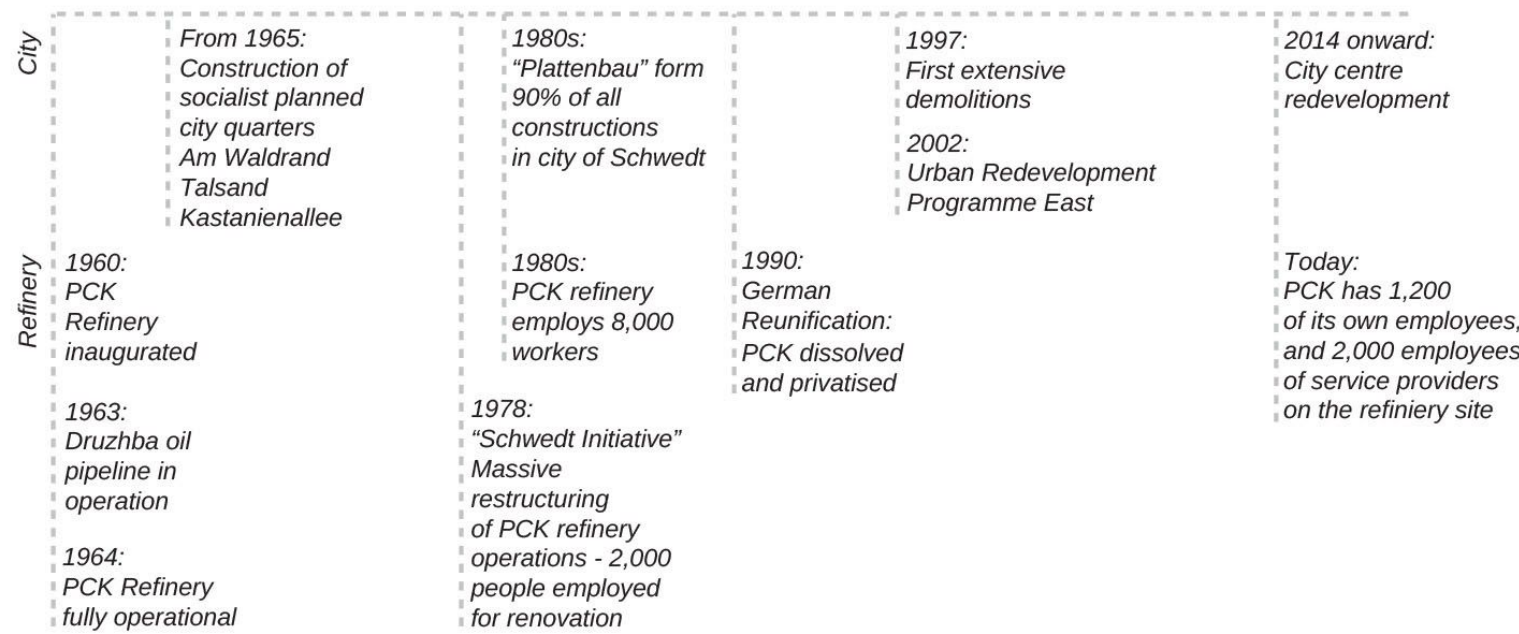

Figure 5. Timeline of Schwedt`s expansion and shrinking Source: Diagram by authors.

\subsection{Expanding vs Shrinking City}

Schwedt's history with planetary urbanization, therefore, dates back to the early 1950s. Simultaneously, several urban planning projects were developed for the town to host workers and their families who would move there in the coming decades to the refinery's commissioning. Construction of socialist planned city quarters such as Am Waldrand, Talsand, Kastanienallee started. During the oil refinery construction, the town's population doubled up to 38.000; in the subsequent decade, it added another ten thousand residents. In those early construction years, there were mainly two groups of inhabitants; workers of PCK and itinerant construction workers who moved from site to site for mega projects to industrialize East Germany. In the corresponding period of the late 1960s through decade, the town expanded with two massive districts, Wohnkomplexe, that each would host fifty-thousand residents. The building boom that corresponded with the city's growth consisted almost entirely of prefabricated concrete GDR Plattenbau buildings. 


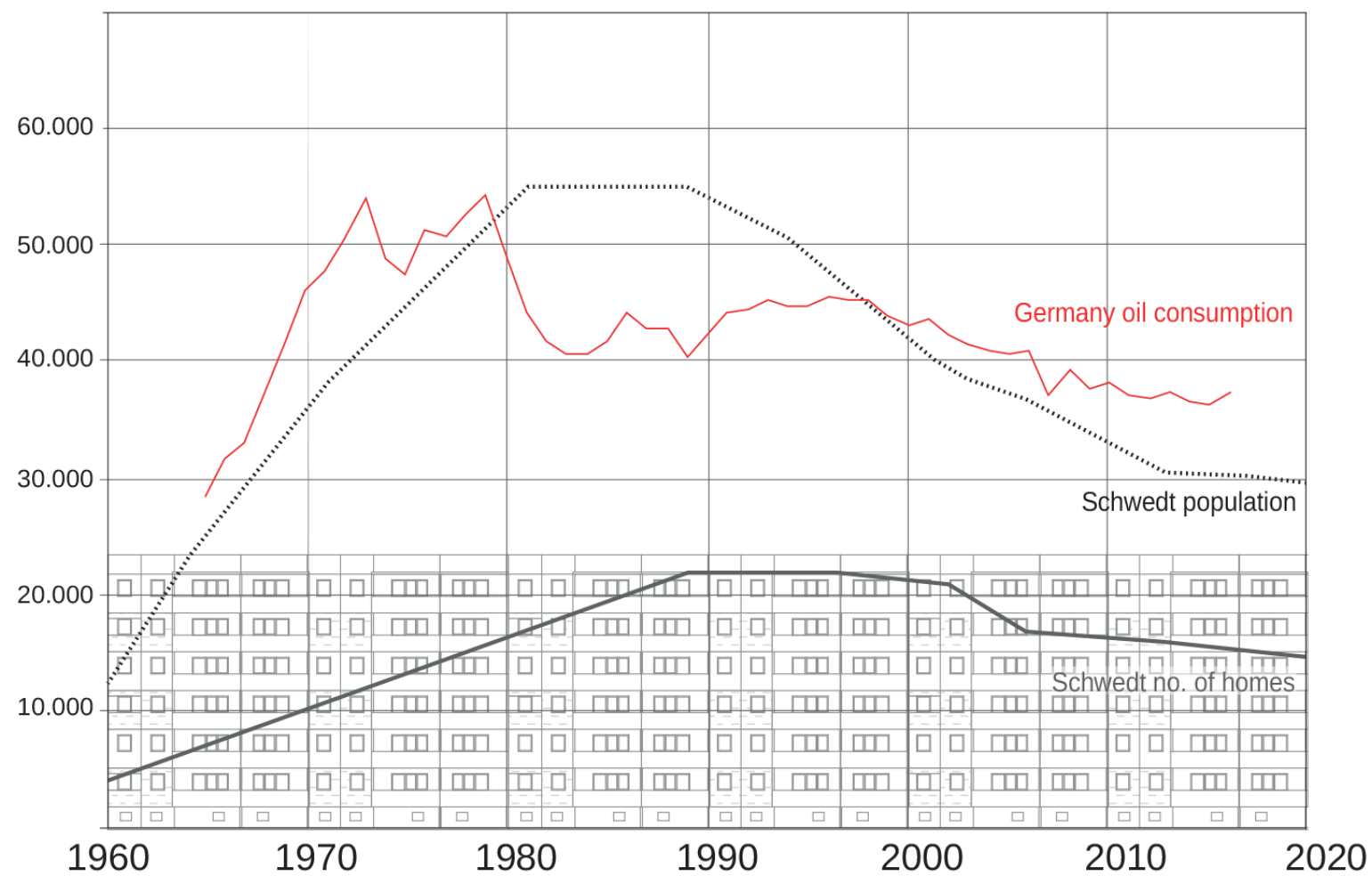

Figure 6. Comparison of Schwedt`s housing stock with Germany`s oil consumption. Source: Diagram by authors.

Commenting on the urban development of cities like Schwedt, Mumford describes the process in two phases. Primarily, there is an intensive act of 'up-building' in which vertical, horizontal industrial and infrastructural clustering occurs, followed by 'un-building, ' the degradation of surrounding landscapes through their role in supplying cities with materials (1938, p. 268). Thus, the 'un-building ' of Schwedt started with the Soviet Union's collapse and continued after German Unification. Recalling the previous section on production networks, the industry of oil production is possible with the availability of materials or serving infrastructure and intensive cooperation of stakeholders. The reasons for Schwedt's shrinkage are likely to correspond with other former-GDR shrinking cities. The city has been steadily shrinking, requiring spatial reorganization to remove derelict housing blocks. As a result, 11,000 homes have been demolished since 1990 to create space for lower density housing, mixed-use developments, and new parks and forests (Rehmann 2014). The monotonous environment of pragmatic industrial urbanism is also to blame,with its lack of amenities and urban functions, they have already caused Schwedt's youthful population of young workers and their families during its 1980s peak, who allegedly struggled with boredom (Kleiner 2015). Furthermore, Schwedt's decline also corresponds with automation in the oil industry and less labor-intensive technologies. Besides, a gradual decline in Germany's oil consumption, which can be attributed to environmental regulations and improvements in fuel efficiency - despite vast and sustained growth in the number of flights since 1990, Germany's consumption of jet fuel has remained roughly stable since 2006 (Pfeiffer and Wigger 2018). 


\subsection{Conclusion}

This study set out to explore the oil industry's spatial configurations by tracing Jet A1 fuel journey from drilling in Russia to distillation in Schwedt until it reached the point of use at Berlin's airports. The flow of oil is explained within the theoretical framework of planetary urbanism as hinterlands, such as the oil drilling equipment, refineries, storage tanks, pipelines, dedicated road and rail infrastructure, airports, and even settlements. Carola Hein explains their role as "nodes in the production, transformation, and distribution of petroleum, which serve as essential drivers of spatial change, over time attracting petrochemical industries, redirecting petroleum flows, reinforcing local petroleum systems, and even translating former-often colonial-dependencies into corporate ones $(2018, p .888)$. As in the refinery in Schwedt, public governments depict oil facilities as a sign of industrial strength and a node for the economic alliance. As a result, spatial planning practices are shaped by collaboration between public and private oil companies, which secures the flows and interests related to petroleum. Furthermore, the existence of extensive petroleum infrastructure has significant staying power. The long life span of petroleum installations and the built environment creates path dependencies, making it incredibly difficult for us to overcome oil dependency and promote new energy practices. In fact the consumption of petroleum products, creating a feedback loop that reinforces the petroleum industry's presence.

With the acknowledgment that the presence of broad petroleum networks has considerable staying power and they are fixed ensembles, and even as petroleum structures disappear, age, or fail, spatial configurations of oil will shape our future (Cooling and Hein, 2018, p. 88). Besides, the utilization of petroleum products creates a cycle that reinforces the presence of the petroleum industry. On the other hand, imaginaries of new landscapes require a rethinking of energy usage and sustainability. An inclusive approach towards physical, corporate, economic factors that drive the spatial development of oil. Therefore, breaking up the cycle requires starting a stream of applied research and developing innovative tools to acquire specific capacities and knowledge and lead to a deep and operative understanding of hinterland dynamics such as facilitates budget air traveling in our case. 


\section{References}

Arboleda, M. (2016) 'In the Nature of the Non-City: Expanded Infrastructural Networks and the Political Ecology of Planetary Urbanisation' in Antipode, 44(2), p.233-251.

Bergin, T. (2008) 'Oil Majors' Output Growth Hinges on Strategy Shift', Reuters, 27 July [online]. Available at: https://ca.reuters.com/article/instant-article/idUKNOA14769420070831 (Accessed: 28 July 2018)

Brenner, N. 'The Hinterland Urbanised?', Architectural Design (2016), 86(4), p118-27.

Brenner, N. and Katsikis, N. (2020) 'Operational landscapes: hinterlands of the Capitalocene', AD/Architectural Design, 90(3), p22-31.

Brenner, N. and Schmid, C. (2012) 'Planetary urbanization' in Gandy,M. (ed.) Urban Constellations. Berlin: Jovis, pp.10-13.

Central Intelligence Agency. (1986) 'East Germany's Economic Ties to The USSR', American Directorate of Intelligence, March [online]. Available at:

https://www.cia.gov/library/readingroom/docs/CIA-RDP08S01350R000601980002-2.pdf(Accessed: 18 August 2020)

Couling, N. and Hein, C. (2018) 'Blankness: The Architectural Void of North Sea Energy Logistics', Delft Architecture Theory Journal, 23, p87-104.

Druzhba Pipeline. Wikipedia [2019) [Online[. Available at: https://en.wikipedia.org/wiki/Druzhba_pipeline (Accessed: 25 July 2019)

Hein, C. (2018) 'Oil Spaces: The Global Petroleumscape in the Rotterdam/the Hague Area' in Journal of Urban History, 44(5), pp. 887-929.

Kleiner, J.P. (2015) 'Schwedt: "A Sanssouci of Socialism"', The GDR Objectified, 23 March [online]. Available at: https:/gdrobjectified.wordpress.com/2015/03/23/schwedt/ (Accessed: 29 July 2019)

Lesch, J. (2000) The German Chemical Industry in the Twentieth Century. Berlin: Springer Science \& Business Media.

Levinson. M. (2008) The Box. Princeton: Princeton University Press.

Marriot, J. and Minio-Palluello, M. (2012) The Oil Road: Journeys from the Caspian Sea to the City of London. London:Verso.

Mumford, L. (1938) The Culture of Cities. 1st edn. New York : Harcourt, Brace and Co. 
Wakeman R. (2014) 'Was There an Ideal Socialist City? Socialist New Towns as Modern Dreamscapes' in Diefendorf J.M., Ward J. (eds) Transnationalism and the German City. Studies in European Culture and History. New York:Palgrave Macmillan ,pp-105-124.

PCK-Raffinerie. Erdölverarbeitungswerk in Schwedt/Oder in Brandenburg. (2019) Wikipedia [Online]. Available at: https://de.wikipedia.org/wiki/PCK-Raffinerie (Accessed: 28 July 2019)

Pfeiffer, U.M. and Wigger, N. (2018) Climate Protection Report. Berlin: BDL Bundesverband der Deutschen Luftverkehrwirtschaft.

Rehmann, B. (2014) RBB24 [Online]. Available at:

https://www.tagesspiegel.de/berlin/immer-weniger-wohnraum-schwedt-eine-stadt-schrumpft/1917980. html (Accessed: 28 July 2019)

Rosneft. (2015) Rosneft Have Closed the Acquisition of 16.67\% Share in Pck Raffinerie Gmbh from Total', Europetrole, 2 December [online]. Available at: https://www.euro-petrole.com/ rosneft-have-closed-the-acquisition-of-16-67-share-in-pck-raffinerie-gmbh-from-total-n-i-12308 (Accessed: 27 July 2019)

Schwedt. (2019) Wikipedia [Online]. Available at: https://en.wikipedia.org/wiki/Schwedt (Accessed: 29 July 2019)

Schwedt Refinery. (2015) A Barrel Full [Online]. Available at: http://abarrelfull.wikidot.com/schwedt-refinery (Accessed: 24 July 2019)

Sordi,J., Valenzuela, L. and Vera, F. (2017) The Camp and the City: Territories of Extraction. E-book format [e-book reader] Available at https://www.gsd.harvard.edu/event/the-camp-and-the-city-territories-of-extraction/ (Accessed: 1 August 2020)

Sternberg, T. 'Alle Tanks Sind Voll - Ölhafen Will Weiter Wachsen', Ostsee Zeitung, [online]. Available at: https://www.ostsee-zeitung.de/Mecklenburg/Rostock/Alle-Tanks-sind-voll-Oelhafen-will-weiter-wachsen (Accessed: 17 July 2019)

Springer, P. (2006) Verbaute Träume: Herrschaft, Stadtentwicklung und Lebensrealität in der sozialistischen Industriestadt Schwedt. 2nd edn. Berlin: Ch. Links Verlag.

USBM. (1981) Minerals Yearbook 1980. 1. Washington: U.S. Bureau of Mines

Visser, B. (2011) 'How Long Can Jet a Be Stored?' General Aviation News, 6 February [online]. Available at: https://generalaviationnews.com/2011/02/06/how-long-can-jet-a-be-stored/ (Accessed: 27 July 2019) 